\title{
Allochthonous dissolved organic matter controls bacterial carbon production in old-growth and clearfelled headwater streams
}

\author{
Ryan M. Burrows ${ }^{1,2,4}$, Jason B. Fellman ${ }^{3,5}$, Regina H. Magierowski ${ }^{1,6}$, AND \\ Leon A. Barmuta ${ }^{1,2,7}$ \\ ${ }^{1}$ School of Zoology, University of Tasmania, Hobart, Tasmania, Australia 7001 \\ ${ }^{2}$ Corporative Research Centre for Forestry, Hobart, Tasmania, Australia 7001 \\ ${ }^{3}$ School of Plant Biology, University of Western Australia, Perth, Western Australia, Australia 6009
}

\begin{abstract}
We investigated how the source and composition of stream dissolved organic matter (DOM) influenced rates of benthic bacterial $\mathrm{C}$ production (BCP) in 20 forested, headwater streams in southern Tasmania. We also assessed whether the source and composition of stream DOM was influenced by clearfell forest harvesting (1-19 y after harvest). Stream DOM was dominated by humic- and fulvic-like fluorescence (86.3-95.5\%) as measured by parallel factor (PARAFAC) analysis of DOM fluorescence. Several reach-scale environmental variables showed significant positive (leaf-area index, sediment total N, organic C) or negative (stream temperature) linear relationships with BCP. However, an increasing contribution of terrestrial DOM, as measured by a decreasing fluorescence index (FI), was the strongest variable driving in situ benthic BCP $\left(R^{2}=0.38, p=0.004, n=20\right)$. Forest harvesting did not significantly affect DOM source despite the major reach-scale disturbance that clearfell forestry represents. Nevertheless, conflicting evidence was found for changes in DOM composition after harvesting. Catchment-scale processes probably are more important than reach-scale processes in determining stream DOM biogeochemistry because clearfelled areas are small relative to the total catchment area. Our results demonstrate that freshly leached, terrestrial DOM can influence stream ecosystem processes through the tight biogeochemical linkage that exists between forested, headwater streams and their surrounding terrestrial environment.
\end{abstract}

Key words: dissolved organic matter, bacterial carbon production, headwater streams, fluorescence, biogeochemistry, PARAFAC, clearfell forestry.

Assimilation of dissolved organic matter (DOM) by heterotrophic bacteria represents one of the largest fluxes of organic C in aquatic ecosystems (Cole 1999, Kritzberg et al. 2005). Therefore, the metabolism of stream DOM, especially in forested headwater streams, has implications for $\mathrm{C}$ cycling in downstream aquatic and near-shore ecosystems. In streams and rivers, bacterial abundance and activity are driven by many factors including the availability of inorganic nutrients (Clapcott and Barmuta 2009), stream and sediment temperature (White et al. 1991, Clapcott and Barmuta 2009), autotrophic production (Bird and Kalff 1984, Rees et al. 2005, del Giorgio and Pace 2008, Guillemette and del Giorgio 2011) and, espe-

\footnotetext{
${ }^{4}$ E-mail addresses: ryan.burrows@utas.edu.au

5 jbfellman@uas.alaska.edu

6 reginam@utas.edu.au

7 leon.barmuta@utas.edu.au
}

cially, DOM source material (Findlay et al. 2003, Docherty et al. 2006, Judd et al. 2006). Therefore, variation in DOM precursors may strongly affect bacterial metabolism by influencing the lability of DOM.

DOM in aquatic ecosystems is derived from either autochthonous or allochthonous sources (Findlay and Sinsabaugh 1999). Autochthonous DOM generally is characterized by protein-like, low-molecular-weight molecules derived from the in-stream metabolism of algae, aquatic macrophytes, and bacterial biomass (Kaplan and Bott 1989, Bertilsson and Jones 2003). Allochthonous DOM consists mainly of aromatic, humic-like molecules derived from the decomposition and leaching of terrestrial plant and soil organic matter (Findlay and Sinsabaugh 1999, McKnight et al. 2001). Conventional wisdom holds that autochthonous DOM is the preferred substrate for aquatic heterotrophic bacteria (Kaplan and Bott 1983, Wetzel 
1992, Kritzberg et al. 2005, Olapade and Leff 2006), but autochthonous DOM production may not be large enough to satisfy overall heterotrophic energy demand (Olapade and Leff 2006). In such systems, allochthonous DOM may be the main energy source for heterotrophic bacteria (McCallister et al. 2004, Kritzberg et al. 2005), mainly because of its abundance. This situation may be especially true for freshly leached allochthonous DOM, which is thought to be highly bioavailable because it is relatively unprocessed by microbes (Amon and Benner 1996).

Anthropogenic disturbance to riparian zones (e.g., forest harvesting) can alter the source and composition of stream DOM by altering hydraulic flow paths (Findlay et al. 2001) and increasing autochthonous DOM production (Johnson et al. 2009). For instance, conversion of forests and wetlands to cropland and urban areas can increase autochthonous DOM production because riparian clearing increases light availability to the channel, and fertilizer and sewage inputs increase nutrient concentrations, which together promote primary production (Walsh et al. 2005, Johnson et al. 2009, Yamashita et al. 2010). Subsequent increases in the labile DOM fraction caused by anthropogenic disturbance can increase the activity of stream heterotrophic bacteria (Williams et al. 2010). Despite these studies in agro-urban landscapes, little is known about how the source and composition of stream DOM influences heterotrophic bacterial activity in predominantly forested landscapes affected by riparian forest harvesting. Understanding the controls on heterotrophic bacteria in forested headwater streams, including the influence of forest harvesting, is important because these factors exert large influences on downstream organic matter and nutrient fluxes (Meyer and Wallace 2001, Wipfli et al. 2007).

Headwater streams in the wet eucalypt forests of southern Tasmania are numerous, have a closed evergreen canopy, and are typically heterotrophdominated systems (Clapcott 2007, Clapcott and Barmuta 2009). Riparian disturbance in the form of clearfell, burn, and sow (CBS) forestry increases algal growth in the short-term ( $<5 \mathrm{y}$ after harvest) (Clapcott and Barmuta 2010). CBS harvesting involves felling of all trees in a forestry coupe (planned harvest area), burning the coupe to provide a receptive mineral seed bed, and sowing seed to facilitate eucalypt regrowth (Hickey and Wilkinson 1999, Forest Practices Board 2000). Headwater streams in southern Tasmania flowing through recently harvested forest probably will show increased autotrophic activity resulting from increased light availability and nutrients, which may increase the supply of autochthonous DOM with a subsequent response in heterotrophic bacterial activity.
Previous research in these headwater streams of southern Tasmania has shown that benthic bacterial C production $(\mathrm{BCP})$ is significantly correlated with stream temperature and total $\mathrm{N}$ (TN) of benthic sediment (Clapcott and Barmuta 2009). However, whether DOM biogeochemistry, which is often a key control on the activity of heterotrophic bacteria (Kritzberg et al. 2005), also influences rates of BCP in benthic sediment of these headwater streams is not known. We evaluated how the source and composition of DOM, measured as the fluorescence characteristics of stream DOM, influenced rates of benthic BCP in forested headwater streams of southern Tasmania. We also examined how forest harvesting (1-19 y after harvest) affected rates of BCP through changes in the source and composition of stream DOM. We expected that increased autotrophic activity associated with CBS forestry would increase the supply of autochthonous relative to allochthonous DOM, which in turn, would increase BCP.

\section{Methods}

\section{Study region and streams}

We conducted our study in the southern half of the Tasmanian Southern Ranges (TSR) bioregion (Thackway and Cresswell 1995). This region has a rugged topography and a temperate climate with mean annual minimum and maximum temperatures of 6 and $17^{\circ} \mathrm{C}$, respectively, and annual rainfall $>1600 \mathrm{~mm}$ (Bureau of Meteorology 2012). Geology of the region is dominated by Permo-Triassic sediments and Jurassic basic igneous rocks (Sharples 1994, Laffan 2001). Soils are well to moderately drained and are generally acidic with a $\mathrm{pH}$ range of 4 to 6 (Thackway and Cresswell 1995, Wells and Hickey 1999). The high rainfall and fertile soils in this region support expansive stands of wet eucalypt forest ( $>385,000 \mathrm{ha}$ ) that are characterized by a canopy of tall eucalypts, predominantly Eucalyptus obliqua (L'Hér), with a dense understory of small trees, broadleaved shrubs, and ferns (Hickey and Wilkinson 1999, Reid et al. 1999).

We chose 20 study streams in which to investigate the influence of DOM and environmental variables on BCP of benthic sediment in coarse gravel habitat (Fig. 1, Table 1). Seventeen of these streams have been subject to CBS forestry along a gradient of time since harvest (TSH; Table 1). Less than $100 \mathrm{~m}$ of each CBSaffected stream reach was directly affected by harvesting because CBS generally occurs at a scale of small coupes distributed throughout the total catchment area. We selected study streams to comply with the following criteria to minimize among-stream 


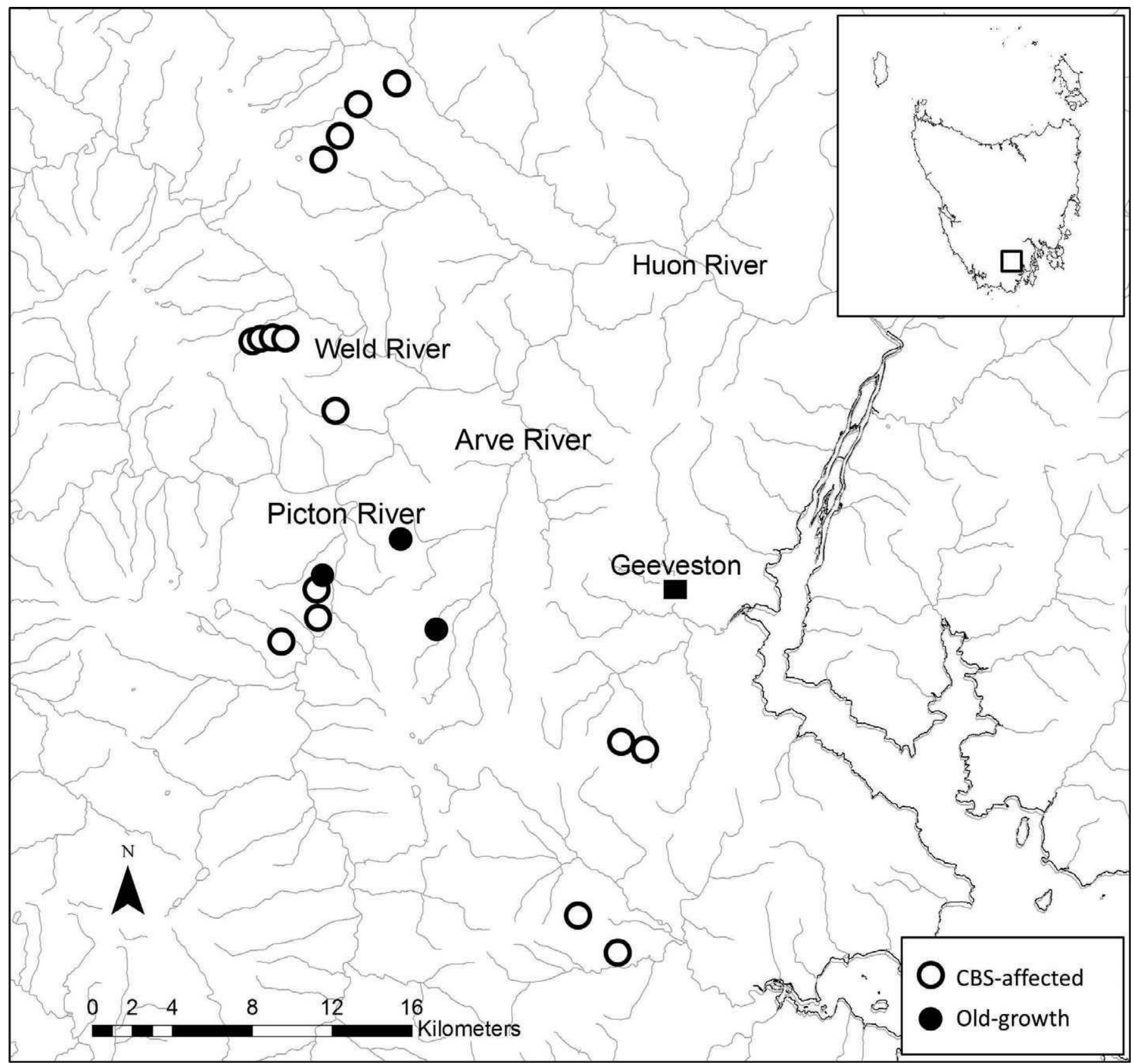

FIG. 1. Locations of 3 old-growth (OG) and seventeen clearfell, burn, and sow (CBS)-affected stream reaches in southern Tasmania. Only larger streams and rivers are shown because smaller streams $\left(1^{\text {st }}\right.$-to $3^{\text {rd }}$-order) are too abundant in the region and have not been accurately mapped.

variability: $1^{\text {st }}$-order streams with permanent surface flow throughout the year, wet eucalypt forest comprising predominantly E. obliqua, similar-sized catchments ( $<50 \mathrm{ha})$, geology dominated by doleritesedimentary complex, and elevation $<600 \mathrm{~m}$ asl. All subcatchments were $<50$ ha, but precise areas could not be measured accurately because of the complex geology (ancient glacial scree deposits) of the region that results in subsurface channels and flow across some topographic divides. Mean stream gradients varied from 5 to $22 \%$ and mean sediment particle size varied from 220 to $1200 \mu \mathrm{m}$ for all streams.

\section{Field sampling}

We sampled all 20 study streams between 31 August 2010 and 7 September 2010 and between 1000 and $1430 \mathrm{~h}$ to reduce diurnal variability. No large 
TABLE 1. Physical characteristics of 20 bacterial C production (BCP) study streams in Tasmania. LAI $=$ leaf-area index. NA refers to streams that have no history of forestry disturbance.

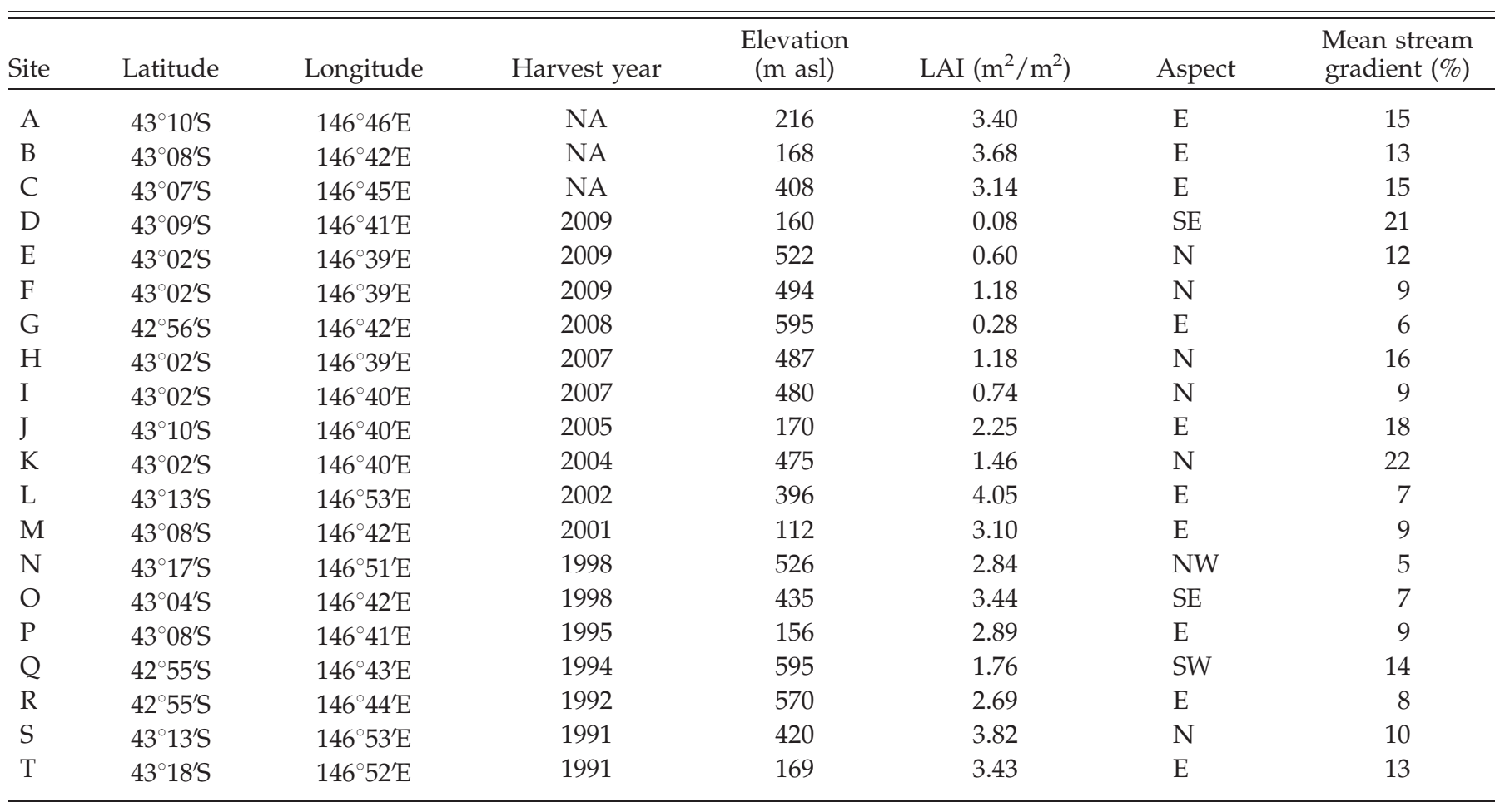

rainstorms occurred during the sampling period. We collected stream water for analysis by fluorescence and ultraviolet (UV) spectroscopy and to measure ambient concentrations of dissolved organic $\mathrm{C}$ (DOC), dissolved organic $\mathrm{N}(\mathrm{DON}), \mathrm{NH}_{4}{ }^{+}, \mathrm{NO}_{3}{ }^{-}$, total $\mathrm{N}$ (TN), total dissolved $\mathrm{N}$ (TDN), soluble reactive $\mathrm{P}$ (SRP), and total P (TP). We filtered water samples for spectroscopic analysis and nutrient concentrations in the field through Millex ${ }^{\circledR}$ HN nylon membrane filters (0.45 $\mu \mathrm{m}$; Merck Millipore, Billerica, Massachusetts) into precleaned $50-\mathrm{mL}$ Sarstedt ${ }^{\circledR}$ PP reagent tubes (Sarstedt, Nümbrecht, Germany), stored samples on ice, and refrigerated them upon return to the laboratory. We rinsed the nylon membrane filters with Milli-Q water (Merck Millipore) and sample water before sample collection. We filtered water samples for DOC analysis in the field through sterile glass-fiber filters (pore size $=0.45 \mu \mathrm{m}$; Type SterileEO; Sartorius Stedim Biotech, Goettingen, Germany) into 40-mL amber glass jars and acidified them with concentrated HCL (1\% of volume).

At each study reach, we measured BCP of coarse gravel benthic sediment, sediment chemical and physical characteristics, algal biomass, and leaf-area index (LAI). We measured BCP with a $\mathrm{C}^{14}$-leucine incorporation into bacterial protein assay following the field methods described by Clapcott and Barmuta (2009). We randomly collected $\sim 50 \mathrm{~g}$ of sediment $(<5$-mm particlesize diameter) from the top $10 \mathrm{~mm}$ of coarse gravel habitat and composited sediment samples in 250-mL clear glass jars for chemical and physical analysis. We transported sediment samples to the laboratory on ice in the dark and froze them in the laboratory for later subsampling for chemical and physical characteristics.

For each stream we assessed chlorophyll $a$ using artificial substrata (ceramic tiles). We placed 4 unglazed ceramic tiles at 4 randomly selected sites along each stream reach for $28 \mathrm{~d}$ (12 October-9 November 2010). We pooled tiles by reach when collected, sealed them in a polyethylene bag, placed them on ice in the dark, and froze them upon return to the laboratory. We estimated leaf-area index (LAI; $\mathrm{m}^{2} / \mathrm{m}^{2}$ ), a tool commonly used as a proxy for light reaching the stream channel (Rich 1990), from hemispherical photographs. At 3 locations along each study reach on 12 October 2010, we took leveled photographs $\sim 15 \mathrm{~cm}$ above the stream with a Nikon CoolPix 950 digital camera with an attached fisheye lens (Nikon, Tokyo, Japan). We analyzed the canopy images with Gap Light Analyzer (GLA) (version 2.0; Frazer et al. 1999). Values of LAI and chlorophyll $a$ could have varied during the time (1-2 mo) between light measurements and measurement of other variables. However, information about their relative 
variation between streams of different harvest histories (i.e., unharvested or TSH) was satisfactory for the purpose of our study.

\section{Laboratory procedures}

We analyzed filtered water samples for DOC (mg C/ L) with a Shimadzu TOC-V CPH/CPN Total Organic Carbon analyzer (Shimadzu, Kyoto, Japan) by the standard American Public Health Association (APHA) method 5310C (APHA 2005). We analyzed stream water TN (mg N/L), $\mathrm{NH}_{4}{ }^{+}(\mathrm{mg} \mathrm{N} / \mathrm{L}), \mathrm{NO}_{3}{ }^{-}(\mathrm{mg} \mathrm{N} / \mathrm{L})$, TDN (mg N/L), SRP (mg P/L), and TP (mg P/L) with standard colorimetric methods (APHA 2005). We calculated DON (mg N/L) by subtracting the sum of dissolved inorganic $\mathrm{N}\left(\mathrm{NH}_{4}{ }^{+}+\mathrm{NO}_{3}{ }^{-}\right)$from TDN.

We measured UV absorbance of filtered water samples warmed to room temperature at $254 \mathrm{~nm}$ with a Hitachi U-1800 UV/VIS spectrophotometer (Hitachi, Tokyo, Japan) within $2 \mathrm{~d}$ of sampling. We analyzed water samples for DOM fluorescence spectroscopy with a Varian Cary Eclipse Fluorometer (Agilent, Santa Clara, California) within 1 wk of sampling. We measured excitation-emission matrices (EEMs) by collecting fluorescence intensity across excitation wavelengths from 240 to $450 \mathrm{~nm}$ (5-nm increments) and emission wavelengths from 300 to $600 \mathrm{~nm}$ (2-nm increments). We measured EEMs at 5-nm bandwidths for excitation and emission at an integration time of 0.25 s. To minimize inner-filter effects, we diluted samples with Milli-Q water to absorbance values $<0.1 /$ $\mathrm{cm}$ measured at $254 \mathrm{~nm}$ (Ohno 2002). We corrected each EEM for instrumental bias with the manufacturer's settings and Raman normalized it using the area under the water Raman peak at excitation wavelength $350 \mathrm{~nm}$.

We followed the method of Buesing and Gessner (2003) and more specifically that of Clapcott and Barmuta (2009) to extract and measure bacterial protein. We washed samples $4 \times$ in $5 \%$ trichloroacetic acid (TCA), $40 \mathrm{mM}$ leucine, $80 \%$ ethanol, and nanopure water, and filtered and centrifuged them before incubating them in $1 \mathrm{~mL}$ of alkaline solution for $60 \mathrm{~min}$ at $90^{\circ} \mathrm{C}$. We transferred a $0.1-\mathrm{mL}$ aliquot of the remaining sample to $2.5 \mathrm{ml}$ of EcoLite ${ }^{\mathrm{TM}}$ scintillation fluid (MP Biomedicals, Santa Ana, California) and allowed it to rest overnight before radioactivity was measured on a Beckman LS6500 scintillation counter (Beckman Coulter, Indianapolis, Indiana). We used moles of exogenous leucine incorporated into bacterial protein $\left(L_{i n c} \mathrm{~mol}\right)$ to calculate $\mathrm{BCP}\left(\mathrm{mg} \mathrm{C} \mathrm{m}^{-2} \mathrm{~d}^{-1}\right)$ with the formula (Clapcott and Barmuta 2009):

$$
B C P=L_{i n c} \times \frac{100}{7.3} \times 131.2 \times 1 \times 0.86
$$

where $100 / 7.3$ is the mol percentage of leucine in protein, 131.2 is the molecular weight of leucine, 1 is a theoretical isotope dilution of leucine (Marxsen 1996, Fischer and Pusch 1999, Buesing and Gessner 2003), and 0.86 is the ratio of cellular $C$ to protein.

We measured chlorophyll $a$ of the algae on ceramic tiles with the method of Biggs and Kilroy (2000). We brushed each tile, washed it with distilled water to remove all algae, and filtered the slurry through a $0.45-\mu \mathrm{m}$ glass-fiber filter. We extracted chlorophyll $a$ with $90 \%$ ethanol. We characterized sediment particle size by sieving up to $20 \mathrm{~g}$ of air-dried sediment for 5 min in a Fritsch Analysette 3 vibratory sieve shaker (Fritsch $\mathrm{GmbH}$, Idar-Oberstein, Germany). We analyzed the resulting mass fractions with GRADISTAT (version 8.0; Kenneth Pye Associates Ltd., Solihull, UK) and expressed the sediment statistics geometrically (Blott and Pye 2001). We analyzed the sediment for TN (mg N/kg) and TP (mg P/kg) by NEPC Method 202 (NEPC 1999) and total organic C (TOC \%) by NEPC Method 105 (NEPC 1999).

\section{Calculations and statistical analyses}

Spectroscopic analyses and parallel factor modeling.We analyzed fluorescence EEMs by parallel factor (PARAFAC) modeling in MATLAB ${ }^{\mathrm{TM}}$ (version 7.5; MathWorks, Natick, Massachusetts) using the PLS toolbox (version 3.5; Eigenvector Research Inc., Wenatchee, Washington) following the procedures of Stedmon and Bro (2008). PARAFAC is a multivariate data analysis that decomposes the fluorescent spectra of DOM into individual fluorescent components (Stedmon and Bro 2008, Fellman et al. 2010). Fluorescent groups do not represent distinct groups of organic compounds, but rather a group of organic compounds with similar fluorescent characteristics (Stedmon and Markager 2005). The PARAFAC model included a total of 83 EEMs to assist in DOM source identification and to incorporate environmental variability. Of the 83 EEMs, 20 were from our study reaches and 63 were additional surface water samples collected from headwater streams during 2010. Before modeling, we corrected the EEMs for Raman and Rayleigh scatter by subtracting the EEM for Milli-Q water and by setting the region of EEM below the Rayleigh peak to 0 (Stedmon and Bro 2008). The PARAFAC model identified a total of 3 unique components within the EEMs and was validated using split-half analysis (Fig. 2A, B). PARAFAC components were reported as a $\%$ relative contribution by using the concentration scores (expressed as $\mathrm{F}_{\max }$ ) for each modeled component and dividing that by the total fluorescence of all the modeled PARAFAC components. 

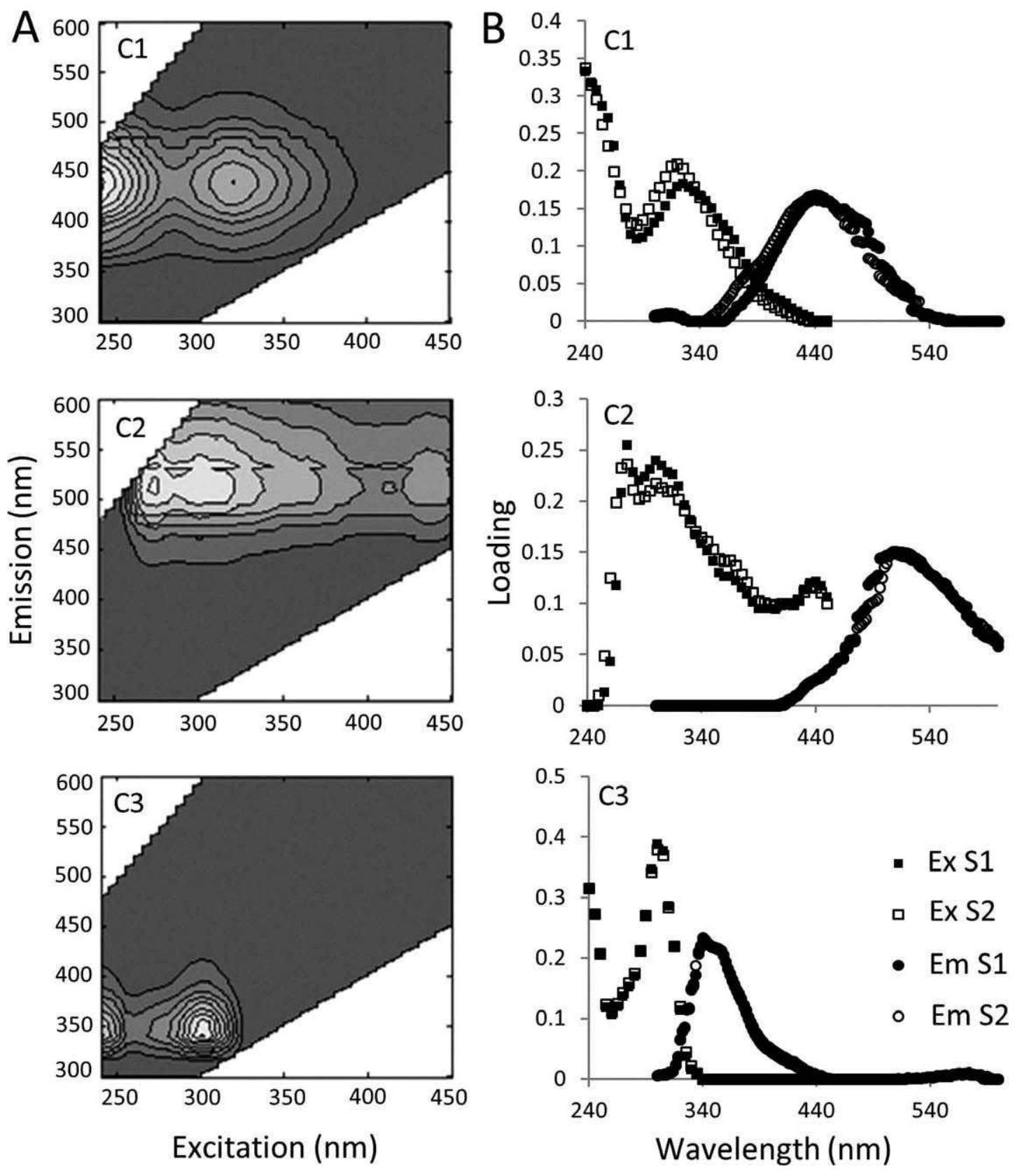

FIG. 2. Spectral characteristics of the 3 parallel factor analysis (PARAFAC) components (A) and the split-half analysis of each component (B). S1 and S2 indicate each half of the data set in the split-half analysis. Intensities are in Raman units. Ex $=$ excitation, $\mathrm{Em}=$ emission, $\mathrm{C} 1=$ Component $1, \mathrm{C} 2=$ Component 2, and $\mathrm{C} 3=$ Component 3.

We measured the specific UV absorbance of DOC $\left(\mathrm{SUVA}_{254}\right)$, which is an indicator of aromatic $\mathrm{C}$ content, by dividing UV absorbance measured at $\lambda$ $=254 \mathrm{~nm}$ by DOC concentration and report it in units of L $\mathrm{mg} \mathrm{C}^{-1} \mathrm{~m}^{-1}$ (Weishaar et al. 2003). We calculated the fluorescence index (FI) for each study stream from the EEMs as the ratio of emission intensities at 470 and $520 \mathrm{~nm}$ at an excitation of $370 \mathrm{~nm}$ (Cory and McKnight 2005, Cory et al. 2010). An FI of 1.2 to 1.4 indicates DOM of terrestrial origin and an FI of 1.7 to 1.9 indicates DOM of predominantly microbial/algal origin (McKnight et al. 2001, Cory et al. 2010).

Effect of CBS forestry on DOM and environmental variables.-We used linear regression between TSH and the \% contribution of each PARAFAC component (and ratios between them), $\mathrm{SUVA}_{254}$, and FI to assess whether a short-term $(<19 \mathrm{y})$ change occurs in the source and composition of DOM after harvesting. We 
TABLE 2. Candidate models used in the Akaike Information Criterion for small samples $\left(\right.$ AIC $\left._{c}\right)$ model selection with bacterial C production $(\mathrm{BCP})$ as the response variable. $K$ indicates the number of model parameters. Variables include stream temperature, sediment total $\mathrm{N}(\mathrm{TN})$, fluorescence index $(\mathrm{FI})$, and FI fitted with a $2^{\text {nd }}$-order polynomial $\left(\mathrm{FI}^{2}\right)$.

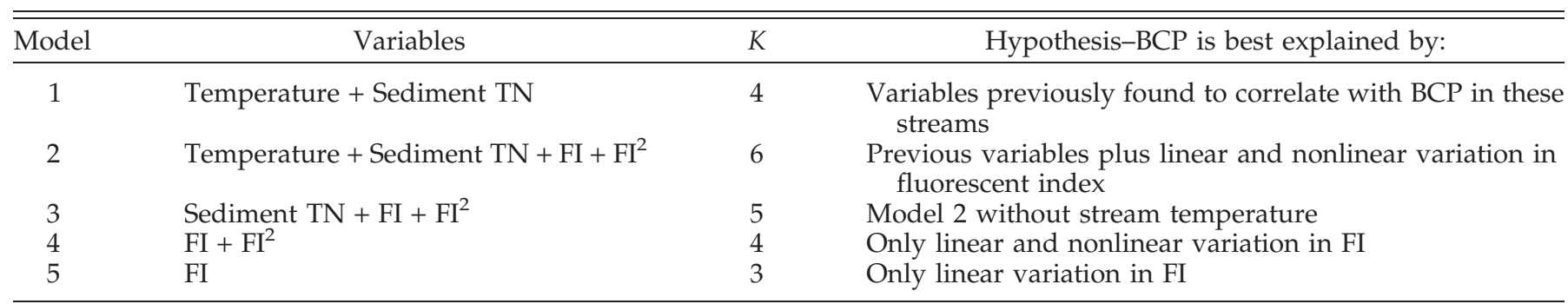

also used linear regression to assess the relationships between TSH and DOC, DON, LAI, chlorophyll $a$, and BCP. We used 2-sample $t$-tests to assess whether an overall gross difference (ignoring harvest year) existed between old-growth (OG) and CBS-affected streams in the \% contribution of each PARAFAC component and ratios between them, $\mathrm{SUVA}_{254}, \mathrm{FI}$, $\mathrm{BCP}$, and the environmental variables. We considered results significant if $p \leq 0.05$, and we checked assumptions using the standard procedures (Quinn and Keough 2002).

Relationships of variables with BCP.-We used Pearson's correlation $(r)$ and univariate linear regressions to explore the relationships between BCP and individual measured environmental and DOM variables. We tabulated $p$-values, but we did not correct them for multiple tests. We used these results merely to provide context for the variable reduction done before formal model testing and to ensure that strong correlates with BCP were not missed in this procedure. For this analysis, we used Akaike's information criterion adjusted for small sample size $(A I C C)$ to assess the relative importance of candidate models for explaining rates of BCP (Burnham and Anderson 2002). TSH was not included in candidate models because this variable excluded the 3 oldgrowth reaches. To avoid collinearity and redundancy between the environmental and DOM variables in our models, we performed variable clustering using Hoeffding's D similarity measure, which accommodates both linear and nonmonotonic relationships between variables (Hoeffding 1948). This procedure separates the variables into clusters that can be scored as a single variable, subsequently resulting in variable reduction (Hoeffding 1948). Following variable reduction, we constructed 5 models based on previous knowledge of what influences rates of $\mathrm{BCP}$ and the examination of the relationship between each variable and $\mathrm{BCP}$ with scatter plots (Table 2). The initial model included stream temperature and sediment TN because these variables previously had been found to be significantly correlated with BCP (Clapcott and Barmuta 2009). We created a model-selection table to rank each candidate model. Models with a low $\triangle A I C c$ $(\leq 2)$ and high Akaike weight (AICc wt) have the best combination of parsimony (fewer parameters) and fit (accuracy) for explaining rates of BCP (Burnham and Anderson 2002). We developed graphs to visualize the relationships among variables included in the best models and BCP. We $\log (x)$ - or $\sqrt{ }(x)$ transformed environmental and DOM data when required to meet the assumptions of normality and equal variance, and checked assumptions using standard diagnostics (Quinn and Keough 2002). We ran all analyses in $\mathrm{R}$ (version 2.12.2; $\mathrm{R}$ Development Core Team, Vienna, Austria).

\section{Results}

\section{$B C P$ and environmental variables}

Rates of BCP varied from 138 to $518 \mathrm{mg} \mathrm{C} \mathrm{m}^{-2} \mathrm{~d}^{-1}$ (Fig. 3A). BCP was poorly related to TSH $\left(R^{2}=0.18, p\right.$ $=0.09)$, and mean BCP was similar in both OG $(277.2$ $\pm 24 \mathrm{mg} \mathrm{C} \mathrm{m}^{-2} \mathrm{~d}^{-1}$ ) and CBS-affected (258.2 \pm $\left.24 \mathrm{mg} \mathrm{C} \mathrm{m}^{-2} \mathrm{~d}^{-1}\right)$ stream reaches $(t=-0.32, p=$ $0.75)$. No environmental variables differed significantly between OG and CBS-affected stream reaches ( $t$-tests, all $p>0.1)$. However, chlorophyll $a$ was significantly negatively related $\left(R^{2}=0.60, p<0.001\right)$ and LAI was significantly positively related $\left(R^{2}=\right.$ $0.64, p<0.001)$ to TSH. Chlorophyll $a$ and LAI also were positively related $(r=0.72)$.

Concentrations of $\mathrm{NH}_{4}{ }^{+}$and $\mathrm{NO}_{3}{ }^{-}$varied from 0.003 to $0.022 \mathrm{mg} \mathrm{N} / \mathrm{L}$ and from 0.002 to $0.480 \mathrm{mg}$ $\mathrm{N} / \mathrm{L}$, respectively. However, values were generally $<0.007 \mathrm{mg} \mathrm{N} / \mathrm{L}$ for $\mathrm{NH}_{4}{ }^{+}$and $0.080 \mathrm{mg} \mathrm{N} / \mathrm{L}$ for $\mathrm{NO}_{3}{ }^{-}$ (Fig. 3B, C). Streamwater concentrations of TDN varied from 0.10 to $0.53 \mathrm{mg} \mathrm{N} / \mathrm{L}$ (Fig. 3D). Sediment TN (230-3400 mg N/kg) (Fig. 3E) and TP (72$790 \mathrm{mg} \mathrm{P} / \mathrm{kg}$ ) (Fig. 3F) varied widely for all sites, but concentrations were positively related $(r=0.49)$. 


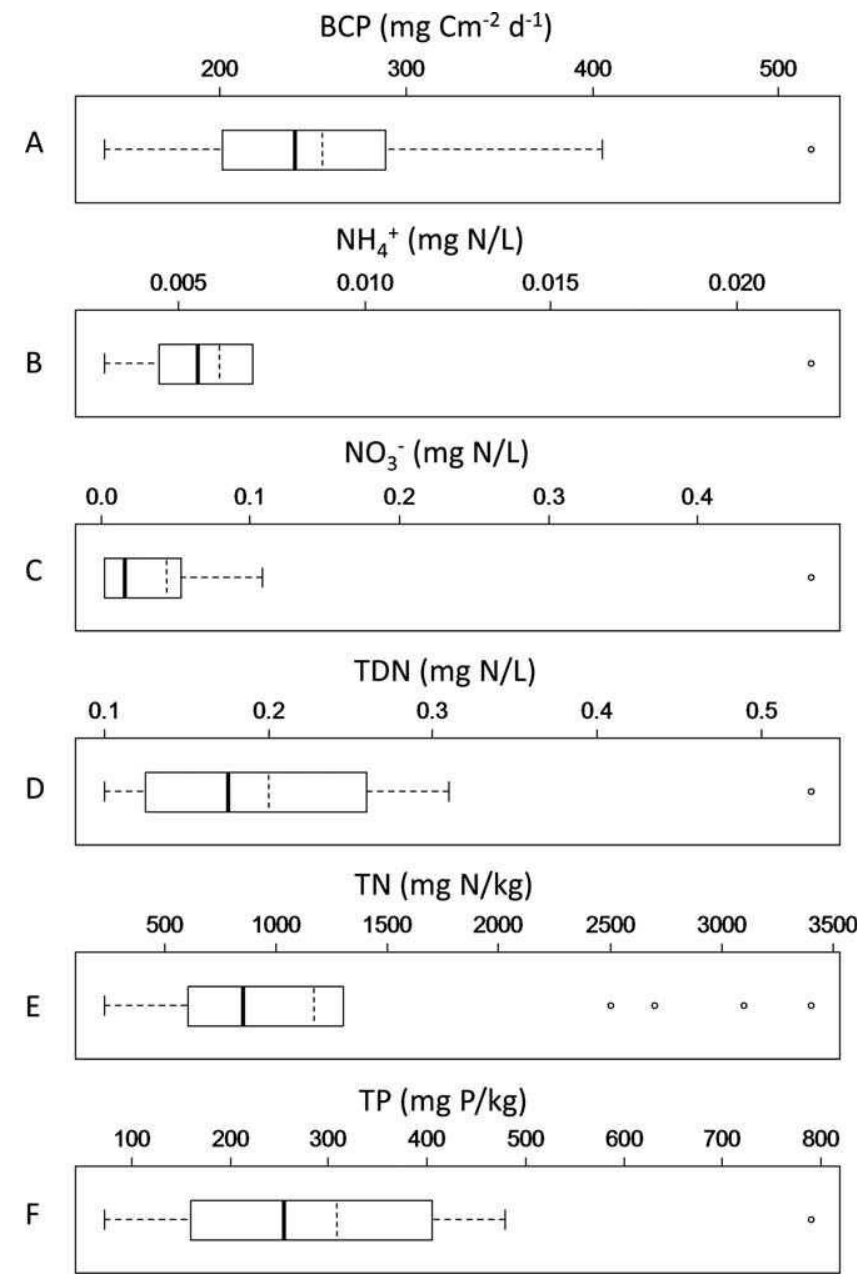

FIG. 3. Box-and-whisker plots for bacterial $\mathrm{C}$ production (BCP) (A), $\mathrm{NH}_{4}{ }^{+}(\mathrm{B}), \mathrm{NO}_{3}{ }^{-}$(C), total dissolved $\mathrm{N}$ (TDN) (D), sediment total $\mathrm{N}(\mathrm{TN})(\mathrm{E})$, and sediment total $\mathrm{P}(\mathrm{TP})(\mathrm{F})$ at 20 study streams in Tasmania. Dotted lines in boxes are means, solid lines in boxes are medians, box ends are $25^{\text {th }}$ and $75^{\text {th }}$ quartiles, whiskers show maximum and minimum values, and dots show outliers.

Sediment TOC varied from 0.2 to $8.3 \%$ (Fig. 4A) and was positively related to sediment TN $(r=0.89)$. DOC varied between 0.9 and $16.0 \mathrm{mg} \mathrm{C} / \mathrm{L}$ (interquartile range: $2-7.2 \mathrm{mg} \mathrm{C} / \mathrm{L}$; Fig. 4B). DON (Fig. $4 \mathrm{C}$ ) was the major component of TDN with a mean contribution of $75 \%$ (interquartile range: 58-95\%). Concentrations of DOC and DON were strongly positively related $(r=$ $0.94)$ but neither showed any relationship with TSH (DOC, $R^{2}=0.15, p=0.13$; DON, $R^{2}=0.10, p=0.20$ ). Chlorophyll $a$ ranged from 0.004 to $0.892 \mathrm{mg} / \mathrm{m}^{2}$ (Fig. 4D). Streamwater nutrients $\left(\mathrm{NO}_{3}{ }^{-}, \mathrm{NH}_{4}{ }^{+}, \mathrm{TDN}\right)$, sediment nutrients (TN, TP) and $\mathrm{C}$ (TOC) concentration were not linearly related to TSH (all $R^{2}<0.05, p$ $>0.3$.

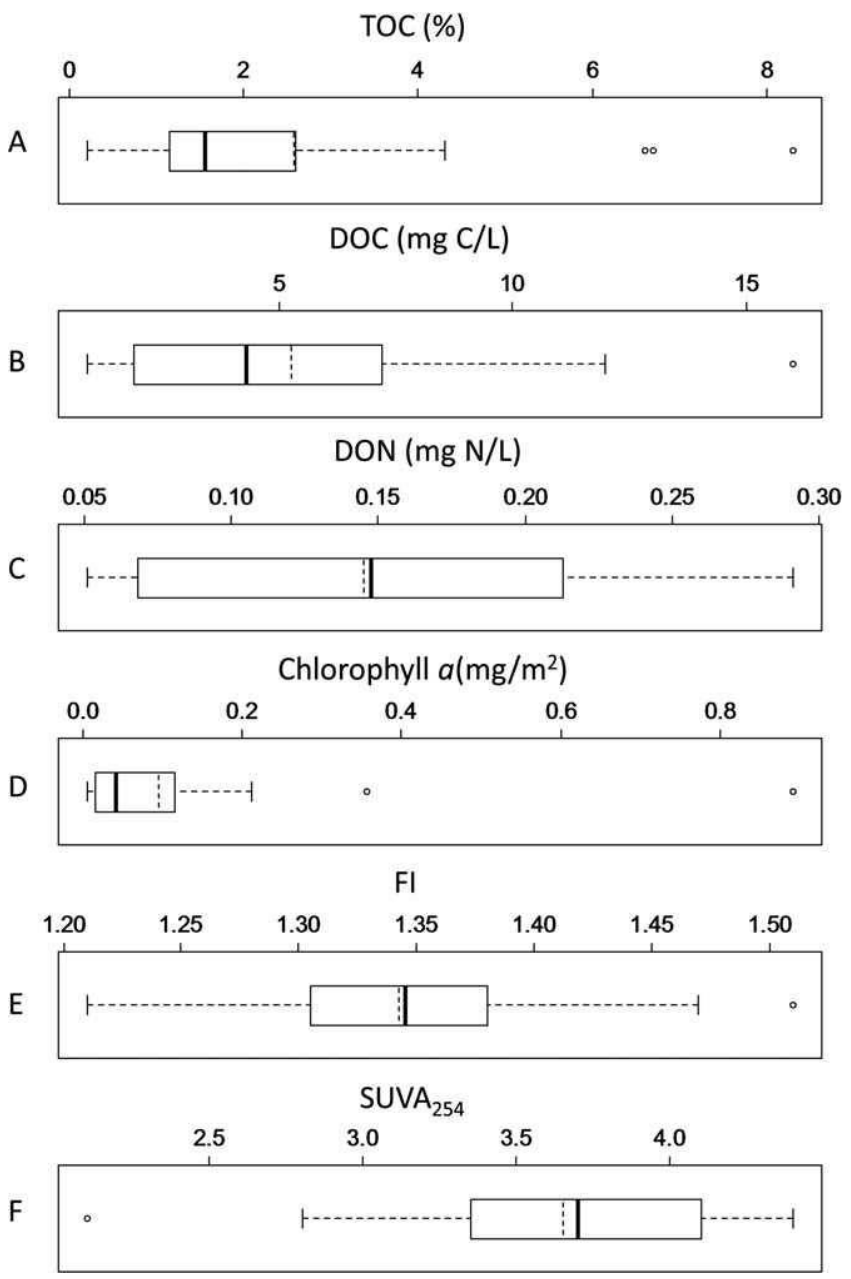

FIG. 4. Box-and-whisker plots for sediment total organic $\mathrm{C}$ (TOC) (A), dissolved organic C (DOC) (B), dissolved organic N (DON) (C), chlorophyll $a(\mathrm{D})$, fluorescence index (FI) (E), and specific UV absorbance $\left(\mathrm{SUVA}_{254}\right)(\mathrm{F})$ at 20 study streams in Tasmania. Dotted lines in boxes are means, solid lines in boxes are medians, box ends are $25^{\text {th }}$ and $75^{\text {th }}$ quartiles, whiskers show maximum and minimum values, and dots show outliers.

\section{FI and SUVA $A_{254}$}

FI values varied between 1.21 and 1.51 (Fig. 4E) and did not show a short-term $(<19 \mathrm{y})$ change after CBS harvesting (linear regression with TSH; $R^{2}=0.07, p=$ $0.7)$. FI values were weakly correlated with LAI $(r=$ $-0.44)$ and were not correlated with chlorophyll $a$ $(r=0.12)$. $\mathrm{SUVA}_{254}$ varied from 2.1 to 4.4 , but values were generally $>3.3$ (Fig. 4F). This range in $\mathrm{SUVA}_{254}$ values corresponds to an aromatic $C$ content of 17 to $32 \%$ (Weishaar et al. 2003). SUVA 254 was not related to TSH $\left(R^{2}=0.20, p=0.07\right)$ or LAI $\left(R^{2}=0.15, p=\right.$ $0.09)$. Values for FI and SUVA $_{254}$ were weakly correlated $(r=-0.44)$ and did not differ between 
TABLE 3. The excitation and emission maximum, relative abundance (\% $\left.\mathrm{F}_{\max }\right)$ of fluorescent components in the 20 bacterial $\mathrm{C}$ production (BCP) study streams, parallel factor (PARAFAC) component references, and description of each component from the 3-component PARAFAC model. 1 = Coble (1996), 2 = Williams et al. (2010), 3 = Stedmon and Markager (2005), $4=$ Cory and McKnight (2005), 5 = Murphy et al. (2006), 6 = Fellman et al. (2008), UVA = ultraviolet A.

\begin{tabular}{|c|c|c|c|c|c|}
\hline Component & $\begin{array}{c}\text { Excitation } \\
\text { maximum }(\mathrm{nm})\end{array}$ & $\begin{array}{c}\text { Emission } \\
\text { maximum }(\mathrm{nm})\end{array}$ & $\% \mathrm{~F}_{\max }$ range & $\begin{array}{c}\text { PARAFAC } \\
\text { component } \\
\text { references }\end{array}$ & Description \\
\hline $\mathrm{C} 2$ & 275 & 508 & $22.9-30.6$ & 2,4 & $\begin{array}{l}\text { Reduced semiquinone-like and soil } \\
\text { fulvic acid-like component; linked } \\
\text { to terrestrial plant matter }\end{array}$ \\
\hline
\end{tabular}

CBS-affected and OG reaches (FI, $t=0.79, p=0.4$; $\left.\mathrm{SUVA}_{254}, t=-1.3, p=0.2\right)$.

\section{EEM-PARAFAC}

PARAFAC analysis of EEMs identified 3 unique fluorescent components (Table 3; Fig. 2A, B). Component 1 (C1), the most abundant fluorescent component (Table 3), has previously been described as a UVA humic-like component resembling fulvic acid derived primarily from terrestrial sources (Coble 1996, Stedmon and Markager 2005, Fellman et al. 2010). Component 2 (C2) has been identified previously as a humic-like component resembling a soil-fulvic acid with semiquinonelike characteristics linked to terrestrial plant matter (Cory and McKnight 2005, Williams et al. 2010). Component 3 (C3) had a primary fluorescence peak at $300 \mathrm{~nm}$ excitation and $340 \mathrm{~nm}$ emission, and resembles a protein-like component (Murphy et al. 2006). The relative abundances of all fluorescence components were similar across the 20 streams (Table 3).

TSH and \% contribution of $\mathrm{C} 1\left(R^{2}=0.06, p=0.3\right.$; Fig. 5A), C2 $\left(R^{2}=0.1, p=0.2\right.$; Fig. $\left.5 \mathrm{~B}\right)$, and C3 $\left(R^{2}=\right.$ $0.1, p=0.1$; Fig. 5C) were not linearly related, indicating no short-term $(<19$ y) change in the fluorescence characteristics of DOM after harvesting. TSH and ratios of PARAFAC components (C1:C3, $\mathrm{C} 1: \mathrm{C} 2$, and $\mathrm{C} 2: \mathrm{C} 3$; all $\left.R^{2}=0.1, p>0.1\right)$ also were not linearly related (ratio data not shown). Percent contribution of $\mathrm{C} 1$ did not differ between OG and CBS streams $(t=-2.1, p=0.051)$, but $\%$ contribution of $\mathrm{C} 2$ was significantly greater $(t=-2.2, p=0.04)$ and of C3 was significantly lower $(t=2.6, p=0.02)$ in OG than CBS streams. C1:C3 and C2:C3 were significantly greater (all $t<-2.1, p<0.01$ ) in OG than CBS streams.
Relationships of BCP with environmental and $D O M$ variables

A variety of environmental variables were significantly, but weakly, related to BCP (linear regression;

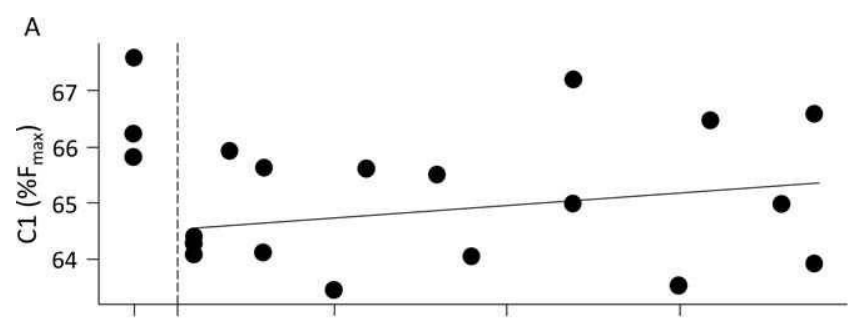

B
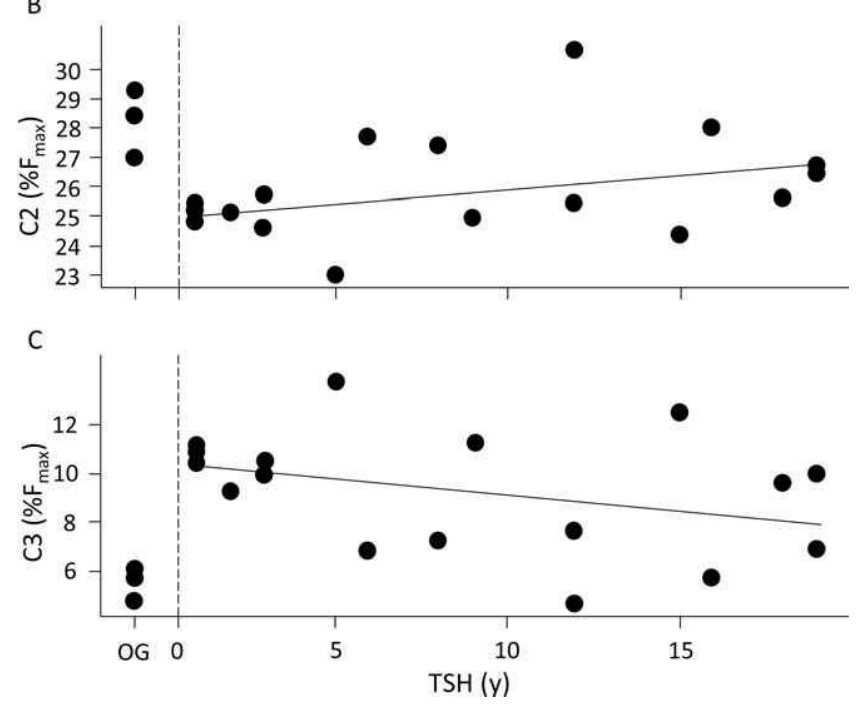

FIG. 5. The relationship between the time since harvest (TSH) and the relative abundance $\left(\% \mathrm{~F}_{\max }\right)$ of humic-like component (C1) (A), fulvic-like component (C2) (B), and protein-like component $(\mathrm{C} 3)(\mathrm{C})$. The relative proportions of parallel factor (PARAFAC) components for old-growth (OG) streams also are displayed. A line of best fit for the regression is overlaid. The slopes of the lines of best fit were not significantly different from $0\left(R^{2} \leq 0.1, p \geq 0.1\right)$. 
TABLE 4. The slope, $R^{2}$, and $p$-values from the simple linear regression between bacterial $C$ production (BCP) and the environmental and dissolved organic matter (DOM) variables in 20 study streams in Tasmania. LAI = leaf-area index, DOC $=$ dissolved organic C, SUVA $_{254}=$ specific ultraviolet absorbance of DOM, TDN $=$ total dissolved $\mathrm{N}$, $\mathrm{DON}=$ dissolved organic $\mathrm{N}, \mathrm{TN}=$ total $\mathrm{N}, \mathrm{TP}=$ total $\mathrm{P}$, $\mathrm{AFDM}=$ ash-free dry mass, $\mathrm{TOC}=$ total organic $\mathrm{C}, \mathrm{FI}=$ fluorescence index, C1-3 = parallel factor components.

\begin{tabular}{|c|c|c|c|}
\hline Variable & Slope & $R^{2}$ & $p$ \\
\hline \multicolumn{4}{|l|}{ Environmental } \\
\hline Time since harvest $(y)$ & 0.40 & 0.02 & 0.5 \\
\hline Altitude (m asl) & 0.00 & 0.00 & 0.9 \\
\hline Stream temperature $\left({ }^{\circ} \mathrm{C}\right)$ & -0.52 & 0.29 & 0.01 \\
\hline Conductivity $(\mu S / \mathrm{cm})$ & -0.16 & 0.00 & 0.9 \\
\hline LAI $\left(\mathrm{m}^{2} / \mathrm{m}^{2}\right)$ & 37 & 0.28 & 0.01 \\
\hline $\mathrm{DOC}(\mathrm{mg} \mathrm{C} / \mathrm{L})$ & 3.4 & 0.02 & 0.5 \\
\hline $\mathrm{NH}_{4}{ }^{+}(\mathrm{mg} \mathrm{N} / \mathrm{L})$ & 2500 & 0.01 & 0.6 \\
\hline $\mathrm{NO}_{3}^{-}(\mathrm{mg} \mathrm{N} / \mathrm{L})$ & -210 & 0.06 & 0.3 \\
\hline TDN (mg N/L) & -62 & 0.00 & 0.8 \\
\hline DON (mg N/L) & 245 & 0.05 & 0.4 \\
\hline Sediment TN (mg N/kg) & 0.05 & 0.32 & 0.01 \\
\hline Sediment TP $(\mathrm{mg} \mathrm{P} / \mathrm{kg})$ & 0.10 & 0.05 & 0.3 \\
\hline Sediment particle size $(\mu \mathrm{m})$ & 0.15 & 0.20 & 0.05 \\
\hline Sediment AFDM $(\%)$ & 6.8 & 0.19 & 0.05 \\
\hline Sediment TOC $(\%)$ & 19 & 0.23 & 0.03 \\
\hline Chlorophyll $a\left(\mathrm{mg} / \mathrm{m}^{2}\right)$ & -160 & 0.13 & 0.1 \\
\hline SUVA $_{254}$ & 63 & 0.17 & 0.07 \\
\hline \multicolumn{4}{|l|}{ DOM } \\
\hline FI & -810 & 0.38 & 0.004 \\
\hline $\mathrm{C} 1$ & 36 & 0.23 & 0.03 \\
\hline $\mathrm{C} 2$ & 10 & 0.04 & 0.4 \\
\hline $\mathrm{C} 3$ & -12 & 0.13 & 0.1 \\
\hline
\end{tabular}

Table 4). However, based on AICc analysis, models incorporating FI and its $2^{\text {nd }}$-order polynomial and these 2 variables combined with sediment TN were the 2 best models that explained rates of $\mathrm{BCP}$ (models 3 and 4 in Table 5). Sediment TN only marginally improved the fit of the model including FI (Table 5), and visual inspection revealed that the relationship between sediment $\mathrm{TN}$ and $\mathrm{BCP}$ was variable at high values of sediment TN (Fig. 6C).

\section{Discussion}

\section{$B C P$ relationships with environmental and DOM variables}

Rates of benthic BCP in our study (138$518 \mathrm{mg} \mathrm{C} \mathrm{m}^{-2} \mathrm{~d}^{-1}$ ) were within the range previously recorded using the same technique in the same region (Clapcott and Barmuta 2009), upland forested streams in central Germany (Marxsen 1996), and a $6^{\text {th }}$-order river in eastern Germany (Fischer and Pusch 2001). Positive relationships between BCP and sediment TN and TOC were similar to those previously found in the same headwater streams (Clapcott and Barmuta
TABle 5. The model number (Table 2), model variables, Akaike Information Criterion for small sample size $\left(A I C_{c}\right)$, change in $A I C_{c}(\triangle A I C c)$, and $A I C c$ weights $(w t)$ used to assess the relative importance of the candidate models for explaining rates of bacterial $\mathrm{C}$ production (BCP) of benthic sediment. Variables include stream temperature, sediment total $\mathrm{N}(\mathrm{TN})$, and fluorescence index (FI).

\begin{tabular}{clccc}
\hline \hline Model & \multicolumn{1}{c}{ Variables } & AICc & $\Delta$ AICc & AICc wt \\
\hline 3 & Sediment TN + FI + FI $^{2}$ & 222.3 & 0.00 & 0.54 \\
4 & FI + FI $^{2}$ & 222.8 & 0.61 & 0.39 \\
2 & Temperature + Sediment $^{2}$ & 226.4 & 4.16 & 0.07 \\
$\quad$ TN + FI + FI & & & \\
5 & FI & 234.0 & 11.8 & 0.00 \\
1 & Temperature + Sediment & 238.0 & 15.8 & 0.00 \\
$\quad$ TN & & & \\
\hline
\end{tabular}

2009). However, we found a moderate, negative relationship $(r=0.54)$ between $\mathrm{BCP}$ and stream temperature in contrast to previous observations (Clapcott 2007). Stream temperature was not very useful for describing BCP in our study because our measurements occurred over a very short time period resulting in a small variation in temperatures (4.8$7.9^{\circ} \mathrm{C}$ ), whereas Clapcott and Barmuta (2009) measured stream temperature over different seasons resulting in a greater range in temperatures (4.7$\left.10.6^{\circ} \mathrm{C}\right)$. Together these findings suggest that stream temperature is not a strong predictor of $\mathrm{BCP}$ over daily time scales, but may be useful in describing overall seasonal patterns.

Several reach environmental variables were important for explaining variations in $\mathrm{BCP}$, but the FI was the strongest variable driving in situ benthic $\mathrm{BCP}$ in our study streams. These results suggest that freshly leached DOM (low FI, 1.2) from terrestrial plant and soil material is readily available to stream bacteria because it is rapidly transported into headwater streams and undergoes minimal microbial processing (Inamdar et al. 2011a). Our hypothesis is further supported by Wickland et al. (2007) whose laboratory incubations showed an increase in the FI of fresh moss leachate from 1.14 to 1.38 over a 3-mo period. This fresh moss leachate was also highly biodegradable (Wickland et al. 2007), and the FI probably increased throughout the incubation because readily available compounds (i.e., fresh leaf leachate) decreased over time because of microbial degradation (Strauss and Lamberti 2002, Findlay et al. 2003). Previous researchers in Arctic rivers also found that DOC was most labile during spring flushing events when terrestrially derived DOC had the shortest soil-residence times and was less degraded than in other seasons (Holmes et al. 2008, Spencer et al. 2008). Overall, our findings are consistent with the idea that relatively unaltered, 

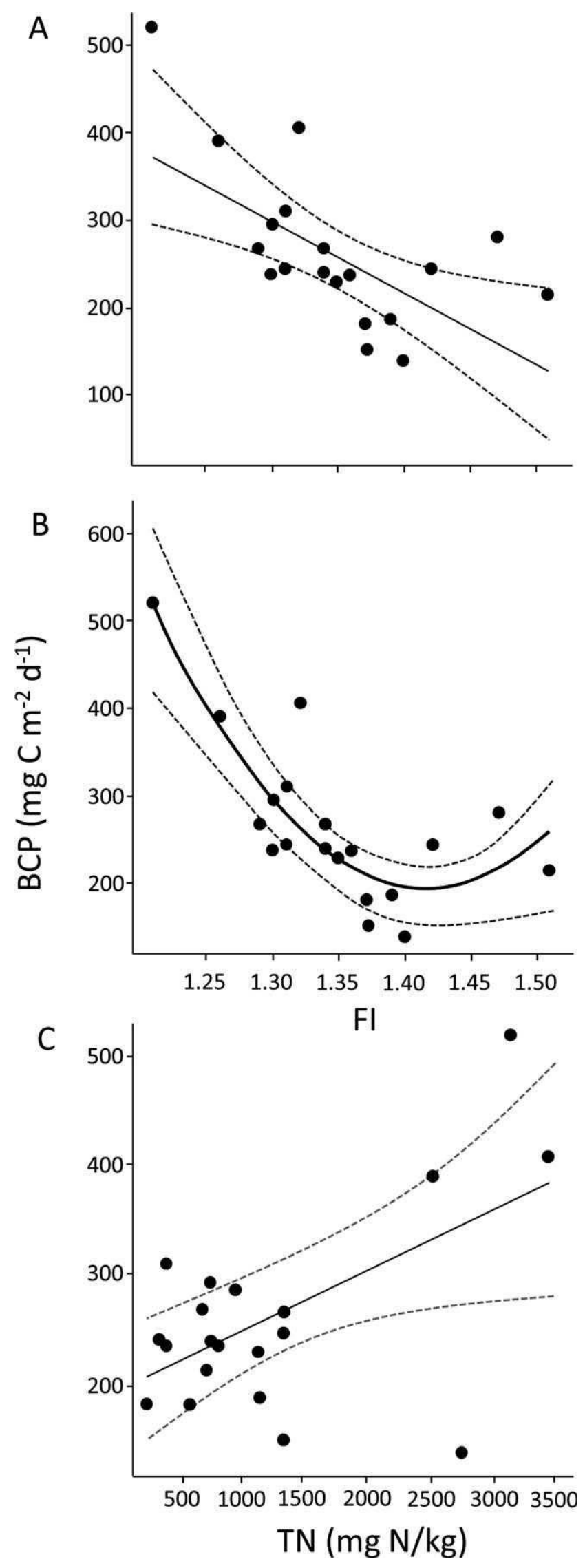

terrestrially derived DOM is highly bioavailable to stream microbial communities (Amon and Benner 1996, Berggren et al. 2009).

$\mathrm{BCP}$ showed a strong negative relationship with FI at low FI values $(<1.4)$, but this relationship appears to switch at FI values $>1.4$, with a possible increasing trend thereafter (Fig. 6B). The limited number of samples with FI values $>1.4$ makes any predictions or explanation difficult, but this trend might possibly continue with increasing FI because autochthonous DOM $(\mathrm{FI} \approx 1.6-1.8)$ typically is highly bioavailable (Kritzberg et al. 2004). We found no evidence of increased algal activity or autochthonous DOM production in the 2 reaches with FI values $>1.4$, but researchers found a significant positive relationship between FI and bacterial production in streams in southern Ontario (Williams et al. 2010). Furthermore, the change in the $\mathrm{BCP}$ trend for FI values $>1.4$ could be driven by characteristics of the stream that we did not measure. For instance, the availability of $P$ can influence bacterial activity in freshwater ecosystems (Smith and Prairie 2004, Jansson et al. 2006), and viral lysis of the bacterial biomass can increase BCP by supplying labile DOM (Pollard and Ducklow 2011).

In contrast to the positive relationship between autochthonous DOM and bacterial activity observed in other environments (Kritzberg et al. 2005, McCallister et al. 2006, Guillemette and del Giorgio 2011), we found no relationship between the protein-like C3 or measured chlorophyll $a$ values and BCP. Two explanations may account for this observed lack of relationship. First, the high proportion of allochthonous DOM in these streams may mask the rapid assimilation of a small pool of highly labile, autochthonous DOM. This idea is supported by research suggesting that even though the algalderived DOM fraction may be quantitatively insignificant, it may still represent the main source of DOM to heterotrophic bacteria (McCallister et al. 2006, Guillemette and del Giorgio 2011). Second, the small supply of autochthonous DOM in these streams (Clapcott and Barmuta 2009) may have resulted in an assemblage of bacterial populations that rely more heavily on the large flux of freshly

FIG. 6. The relationships between benthic bacterial $\mathrm{C}$ production (BCP) and the fluorescence index (FI) of stream water modeled with linear regression (A), FI modeled with polynomial regression (B), and benthic sediment total $\mathrm{N}$ (TN) (C). Curves of best fit are overlaid with $95 \%$ confidence intervals. 
leached, bioavailable allochthonous DOM. Previous research shows that the composition of bacterial populations can shift in response to variation in the supply and quality of DOM over relatively short periods of time (Findlay et al. 2003, Docherty et al. 2006, Judd et al. 2006). Therefore, assimilation of terrestrially derived DOM by benthic bacteria may be an adaptive response to its abundance and bioavailability in this region.

We measured in situ BCP and collected water samples during early spring (September), and it is possible that the observed relationship between terrestrial $\mathrm{DOM}$ and $\mathrm{BCP}$ may differ seasonally because of variations in litter input, algal activity, and subsequent autochthonous DOM production. For instance, many investigators have observed changes in DOM characteristics between seasons (Jaffé et al. 2008), and researchers in headwater streams in southern Tasmania found bacterial activity peaks in summer (Clapcott and Barmuta 2009). Litter input in temperate, wet eucalypt forest peaks in summer or early autumn (Ashton 1975). We think it likely that this peak corresponds with entry of high levels of fresh DOM leachate into streams and could potentially contribute to the increased heterotrophic bacteria activity observed in southern Tasmania (Clapcott and Barmuta 2009). In addition, relationships between DOM characteristics and BCP may differ with stream discharge because high-flow events can substantially increase stream DOM concentration (Hinton et al. 1997) and can increase the proportion of humic-like DOM components in upland watersheds (Fellman et al. 2009, Inamdar et al. 2011b).

\section{Forest harvesting influence on DOM source and composition}

We did not detect a difference in DOM source between OG and CBS-affected streams even though CBS harvesting is a major riparian and forest disturbance. However, we did find evidence of changes in DOM composition after harvesting, with a higher relative abundance of humic-like (ratio data only) and fulvic-like, but lower relative abundance of protein-like, compounds in OG than CBS-affected reaches. This finding is consistent with previous research in which reference streams had higher levels of humic-like but lower protein-like DOM fluorescence than clearcut (30 y since harvesting) or pine plantation (50 y since conversion) watersheds in western North Carolina (Yamashita et al. 2011). The long-term effects (up to $50 \mathrm{y}$ ) on stream DOM composition found by Yamashita et al. (2011) suggest that recovery of DOM composition to preharvest levels in Tasmania may take much longer than the $19 \mathrm{y}$ since harvest used in our study. The positive (humiclike) and negative (protein-like) trends in the relative abundance of DOM fluorescence compounds with TSH support this notion. These relationships are not significant, but they indicate a slow return to preharvest levels (Fig. 5A-C).

Drawing strong conclusions about how DOM biogeochemistry differs between OG and CBS-affected streams is difficult because of the small number of OG streams $(n=3)$ and the fact that we sampled only once in each stream. Nevertheless, one possible reason for the observed similarity between OG and CBS-affected streams is that any potential increase in autochthonous DOM in CBS-affected streams may be masked by its rapid consumption because of high DOM bioavailability (Kritzberg et al. 2004, McCallister et al. 2006). A $2^{\text {nd }}$ reason is that any change in DOM source and composition (i.e., increased algae-derived and protein-like DOM after forest harvesting) may be difficult to detect because it probably is minimal relative to the large flux of terrestrial DOM delivered to the stream. Thus, the contribution of autochthonous DOM may be minimal in harvested streams because only a small proportion of the total channel length $(<100 \mathrm{~m})$ usually is affected by CBS forestry during any one harvest event. This idea is supported by studies in the Pacific Northwest (USA) and the Canadian Boreal Shield in which catchment-scale characteristics more strongly influenced in-stream properties (fine particulate organic matter, leaf decomposition, and macroinvertebrate communities) than reach-scale changes caused by forest-harvesting activity (Kreutzweiser et al. 2008, Sakamaki and Richardson 2011).

\section{Catchment-scale implications}

Overall, our findings show that freshly leached, terrestrial DOM with a low FI $(<1.3)$ can be an important energy source in forested, headwater streams. Consequently, DOM delivered to headwater streams may be rapidly processed and modified in composition as it is transported downstream. Future research is needed that is focused on this tight terrestrial-aquatic DOM linkage and, in particular, on how seasonal variation in litter input may influence aquatic bacterial activity. For instance, the relationship between DOM source and aquatic bacterial activity may change in the cooler months when terrestrial leaf-litter input is low, leading to seasonal variability in the quantity and lability of DOM transported downstream.

Forest harvesting had little unequivocal influence on DOM fluorescence characteristics. We found some 
evidence for changes in DOM composition but no changes in the source of DOM as measured by the FI. We suggest that catchment-scale processes may be more important than reach-scale processes (i.e., those affected by individual harvested areas) in driving DOM characteristics in headwater streams flowing through wet eucalypt forests of southern Tasmania. However, as the proportion of OG forest in a given catchment is reduced through ongoing forestry, more autochthonous DOM might be produced, and this DOM will potentially stimulate bacterial activity. Therefore, consideration of the intensity and extent of CBS forestry within a catchment probably is important, and the dispersal of CBS operations in space and time may help minimize its negative effects on headwater and downstream aquatic ecosystems.

\section{Acknowledgements}

We thank K. Hawkes, E. Polymeropoulos, T. Hollings, J. Haag, J. Fountain, S. Griffin, A. Brüniche-Olsen, J. Kramer, J. Goon, K. Kreger, and C. Spencer for their field assistance. We also thank Forestry Tasmania who granted access to the study sites and the staff at Geeveston for their support. We thank 2 anonymous referees for their detailed comments. RMB received a postgraduate scholarship funded by the CRC for Forestry and the School of Zoology, University of Tasmania. Further financial and in-kind support was provided by the Forest Practices Authority Tasmania and School of Zoology at the University of Tasmania. S. Munks (Forest Practices Authority), P. E. Davies (University of Tasmania), and S. Roberts (Forestry Tasmania) provided comments and advice throughout the project.

\section{Literature Cited}

AMOn, R. M. W., AND R. BENNER. 1996. Bacterial utilization of different size classes of dissolved organic matter. Limnology and Oceanography 41:41-51.

APHA (American Public Health Association). 2005. Standard methods for the examination of water and wastewater. $21^{\text {st }}$ edition. American Public Health Association, American Water Works Association, and Water Environment Federation, Washington, DC.

Ashton, D. 1975. Studies of litter in Eucalyptus regnans forests. Australian Journal of Botany 23:413-433.

Berggren, M., H. Laudon, And M. Jansson. 2009. Aging of allochthonous organic carbon regulates bacterial production in unproductive boreal lakes. Limnology and Oceanography 54:1333-1342.

Bertilsson, S., And J. N. Jones. 2003. Supply of dissolved organic matter to aquatic ecosystems: autochthonous sources. Pages 3-19 in S. E. G. Findlay and R. L. Sinsabaugh (editors). Aquatic ecosystems: interactivity of dissolved organic matter. Academic Press, Burlington, Massachusetts.

Biggs, B. J. F., And C. Kilroy. 2000. Stream periphyton monitoring manual. National Institute of Water and Atmospheric Research for New Zealand Ministry for the Environment, Christchurch, New Zealand. (Available from: http:/ / www.niwa.co.nz/our-science/freshwater/ tools/periphyton)

BIRD, D. F., AND J. KALFF. 1984. Empirical relationships between bacterial abundance and chlorophyll concentration in fresh and marine waters. Canadian Journal of Fisheries and Aquatic Sciences 41:1015-1023.

Blott, S. J., AND K. Pye. 2001. GRADISTAT: a grain size distribution and statistics package for the analysis of unconsolidated sediments. Earth Surface Processes and Landforms 26:1237-1248.

Buesing, N., AND M. O. Gessner. 2003. Incorporation of radiolabeled leucine into protein to estimate bacterial production in plant litter, sediment, epiphytic biofilms, and water samples. Microbial Ecology 45:291-301.

Bureau of Meteorology. 2012. Tasmanian annual climate summary archive. Australian Government, Melbourne, Australia. (Available from: http://www.bom.gov.au/ climate/current/annual/tas/archive/)

Burnham, K. P., And D. R. Anderson. 2002. Model selection and multimodel inference: a practical informationtheoretic approach. Springer, New York.

ClapcotT, J. E. 2007. The metabolic signature of small headwater streams: natural variability and the response to forestry. PhD Thesis, University of Tasmania, Hobart, Australia.

Clapcott, J. E., and L. A. Barmuta. 2009. Metabolic patch dynamics in small headwater streams: exploring spatial and temporal variability in benthic processes. Freshwater Biology 55:806-824.

Clapcott, J. E., and L. A. Barmuta. 2010. Forest clearance increases metabolism and organic matter processes in small headwater streams. Iournal of the North American Benthological Society 29:546-561.

CoвLe, P. G. 1996. Characterization of marine and terrestrial DOM in seawater using excitation-emission matrix spectroscopy. Marine Chemistry 51:325-346.

Cole, J. J. 1999. Aquatic microbiology for ecosystem scientists: new and recycled paradigms in ecological microbiology. Ecosystems 2:215-225.

Cory, R. M., AND D. M. McKnight. 2005. Fluorescence spectroscopy reveals ubiquitous presence of oxidized and reduced quinones in dissolved organic matter. Environmental Science and Technology 39:8142-8149.

Cory, R. M., M. P. Miller, D. M. McKnight, J. J. Guerard, AND P. L. Miller. 2010. Effect of instrument-specific response on the analysis of fulvic acid fluorescence spectra. Limnology and Oceanography: Methods 8: $67-78$.

Del Giongio, P. A., And M. L. PACE. 2008. Relative independence of dissolved organic carbon transport and processing in a large temperate river: the Hudson River as both pipe and reactor. Limnology and Oceanography 53:185-197. 
Docherty, K. M., K. C. Young, P. A. Maurice, and S. D. BRIDGHAM. 2006. Dissolved organic matter concentration and quality influences upon structure and function of freshwater microbial communities. Microbial Ecology 52:378-388.

Fellman, J. B., D. V. D’Amore, E. Hood, and R. D. Boone. 2008. Fluorescence characteristics and biodegradability of dissolved organic matter in forest and wetland soils from coastal temperate watersheds in southeast Alaska. Biogeochemistry 88:169-184.

Fellman, J. B., E. Hood, R. T. Edwards, and D. V. D'Amore. 2009. Changes in the concentration, biodegradability, and fluorescent properties of dissolved organic matter during stormflows in coastal temperate watersheds. Journal of Geophysical Research G: Biogeosciences 114. doi:10.1029/2008JG00790.

Fellman, J. B., E. Hood, and R. G. M. Spencer. 2010. Fluorescence spectroscopy opens new windows into dissolved organic matter dynamics in freshwater ecosystems: a review. Limnology and Oceanography 55:2452-2462.

Findlay, S., J. M. Quinn, C. W. Hickey, G. Burrell, and M. DOWNES. 2001. Effects of land use and riparian flowpath on delivery of dissolved organic carbon to streams. Limnology and Oceanography 46:345-355.

FindLAY, S., AND R. L. SinSABAUGH. 1999. Unravelling the sources and bioavailability of dissolved organic matter in lotic aquatic ecosystems. Marine and Freshwater Research 50:781-790.

Findlay, S. E. G., R. L. Sinsabaugh, W. V. Sobczak, and M. Hoostal. 2003. Metabolic and structural response of hyporheic microbial communities to variations in supply of dissolved organic matter. Limnology and Oceanography 48:1608-1617.

Fischer, H., AND M. Pusch. 1999. Use of the [14C]leucine incorporation technique to measure bacterial production in river sediments and the epiphyton. Applied and Environmental Microbiology 65:4411-4418.

Fischer, H., AND M. Pusch. 2001. Comparison of bacterial production in sediments, epiphyton and the pelagic zone of a lowland river. Freshwater Biology 46: 1335-1348.

Forest Practices Board. 2000. Forest Practices Code. Forest Practices Board, Hobart, Australia. (Available from: http://www.fpa.tas.gov.au/)

Frazer, G. W., C. D. Canham, and K. P. Lertzman. 1999. Gap Light Analyzer (GLA): imaging software to extract canopy structure and gap light transmission indices from true-colour fisheye photographs, users manual and program documentation. Simon Fraser University, Burnaby, British Columbia, and the Institute of Ecosystem Studies, Millbrook, New York.

Guillemette, F., AND P. A. DEl Giorgio. 2011. Reconstructing the various facets of dissolved organic carbon bioavailability in freshwater ecosystems. Limnology and Oceanography 56:734-748.

Hickey, J. E., AND G. R. WiLKInSON. 1999. The development and current implementation of silvicultural practices in native forests in Tasmania. Australian Forestry 62: 245-254.

Hinton, M. J., S. L. Schiff, and M. C. English. 1997. The significance of storms for the concentration and export of dissolved organic carbon from two Precambrian Shield catchments. Biogeochemistry 36:67-88.

HoefFDinG, W. 1948. A non-parametric test of independence. Annals of Mathematical Statistics 19:546-557.

Holmes, R. M., J. W. McClelland, P. A. Raymond, B. B. Frazer, B. J. Peterson, And M. Stieglitz. 2008. Lability of DOC transported by Alaskan rivers to the Arctic Ocean. Geophysical Research Letters 35 doi:10.1029/ 2007 GL032837.

Inamdar, S., N. Finger, S. Singh, M. Mitchell, D. Levia, H. Bais, D. Scott, And P. McHale. 2011a. Dissolved organic matter (DOM) concentration and quality in a forested mid-Atlantic watershed, USA. Biogeochemistry 108: 55-76.

Inamdar, S., S. Singh, S. Dutta, D. Levia, M. Mitchell, D. Scott, H. BAIS, AND P. McHale. 2011b. Fluorescence characteristics and sources of dissolved organic matter for stream water during storm events in a forested midAtlantic watershed. Journal of Geophysical Research G: Biogeosciences 116. doi:10.1029/2011JG001735.

Jaffé, R., D. McKnight, N. Maie, R. Cory, W. H. McDowell, AND J. L. CAMPBELl. 2008. Spatial and temporal variations in DOM composition in ecosystems: the importance of long-term monitoring of optical properties. Journal of Geophysical Research G: Biogeosciences 113. doi:10. 1029/2008JG000683.

Jansson, M., A. K. Bergström, D. Lymer, K. VRede, and J. KARLSSON. 2006. Bacterioplankton growth and nutrient use efficiencies under variable organic carbon and inorganic phosphorus ratios. Microbial Ecology 52: 358-364.

Johnson, L. T., J. L. TAnK, and C. P. Arango. 2009. The effect of land use on dissolved organic carbon and nitrogen uptake in streams. Freshwater Biology 54:2335-2350.

Judd, K. E., B. C. CRumP, AND G. W. KLING. 2006. Variation in dissolved organic matter controls bacterial production and community composition. Ecology 87:2068-2079.

Kaplan, L. A., AND T. L. Bott. 1983. Microbial heterotrophic utilization of dissolved organic matter in a piedmont stream. Freshwater Biology 13:363-377.

Kaplan, L. A., AND T. L. BotT. 1989. Diel fluctuations in bacterial activity on streambed substrata during vernal algal blooms: effects of temperature, water chemistry, and habitat. Limnology and Oceanography 34:718-733.

Kreutzweiser, D. P., K. P. Good, S. S. Capell, and S. B. Holmes. 2008. Leaf-litter decomposition and macroinvertebrate communities in boreal forest streams linked to upland logging disturbance. Iournal of the North American Benthological Society 27:1-15.

Kritzberg, E. S., J. J. Cole, M. L. Pace, W. Granéli, and D. L. BADE. 2004. Autochthonous versus allochthonous carbon sources of bacteria: results from whole-lake ${ }^{13} \mathrm{C}$ addition experiments. Limnology and Oceanography 49:588-596.

Kritzberg, E. S., J. J. Cole, M. M. Pace, and W. Granéli. 2005. Does autochthonous primary production drive 
variability in bacterial metabolism and growth efficiency in lakes dominated by terrestrial $C$ inputs Aquatic Microbial Ecology 38:103-111.

LAFFAN, M. D. 2001. Geology and soils in the Warra LTER site: a preliminary description. Tasforests 13:23-29.

MARXSEN, J. 1996. Measurement of bacterial production in stream-bed sediments via leucine incorporation. FEMS Microbiology Ecology 21:313-325.

McCallister, S. L., J. E. Bauer, and E. A. Canuel. 2006. Bioreactivity of estuarine dissolved organic matter: a combined geochemical and microbiological approach. Limnology and Oceanography 51:94-100.

McCallister, S. L., J. E. Bauer, J. E. Cherrier, and H. W. DuCKLOW. 2004. Assessing sources and ages of organic matter supporting river and estuarine bacterial production: a multiple-isotope $\left(\delta^{14} \mathrm{C}, \delta^{13} \mathrm{C}\right.$, and $\left.\delta^{15} \mathrm{~N}\right)$ approach. Limnology and Oceanography 49:1687-1702.

McKnight, D. M., E. W. Boyer, P. K. Westerhoff, P. T. Doran, T. Kulbe, AND D. T. Anderson. 2001. Spectrofluorometric characterization of dissolved organic matter for indication of precursor organic material and aromaticity. Limnology and Oceanography 46:38-48.

Meyer, J. L., And J. B. Wallace. 2001. Lost linkages and lotic ecology: rediscovering small streams. Pages 295-317 in M. C. Press, N. J. Huntley, and S. A. Levin (editors). Ecology: achievement and challenge. Blackwell, Cornwall, UK.

Murphy, K. R., G. M. Ruiz, W. T. M. Dunsmuir, and T. D. WAITE. 2006. Optimized parameters for fluorescencebased verification of ballast water exchange by ships. Environmental Science and Technology 40: 2357-2362.

NePC (National Environment Protection Council). 1999. National Environment Protection (Assessment of Site Contamination) Measure: schedule $\mathrm{B}(3)$ guideline on laboratory analysis of potentially contaminated soils. National Environment Protection Council, Canberra, Australia.

OHNO, T. 2002. Fluorescence inner-filtering correction for determining the humification index of dissolved organic matter. Environmental Science and Technology 36: 742-746.

Olapade, O. A., AND L. G. LefF. 2006. Influence of dissolved organic matter and inorganic nutrients on the biofilm bacterial community on artificial substrates in a northeastern Ohio, USA, stream. Canadian Journal of Microbiology 52:540-549.

Pollard, P. C., AND H. Ducklow. 2011. Ultrahigh bacterial production in a eutrophic subtropical Australian river: does viral lysis short-circuit the microbial loop? Limnology and Oceanography 56:1115-1129.

Quinn, G. P., And M. J. KeOugh. 2002. Experimental design and data analysis for biologists. Cambridge University Press, Cambridge, UK.

Rees, G. N., G. Beattie, P. M. Bowen, and B. T. Hart. 2005. Heterotrophic bacterial production in the lower Murray River, south-eastern Australia. Marine and Freshwater Research 56:835-841.
Reid, J. B., R. S. Hill, M. J. Brown, and M. J. Hovenden. 1999. Vegetation of Tasmania. Australian Biological Resources Study, Hobart, Tasmania.

Rich, P. M. 1990. Characterizing plant canopies with hemispherical photographs. Remote Sensing Reviews 5:13-29.

SAKAMAKI, T., AND J. S. RichardSON. 2011. Biogeochemical properties of fine particulate organic matter as an indicator of local and catchment impacts on forested streams. Iournal of Applied Ecology 48:1462-1471.

SHARPLES, C. 1994. Landforms and geological sites of geoconservation significance in the Huon Forest District. Volume 2. Description. Forestry Tasmania, Hobart, Australia.

Smith, E. M., AND Y. T. Prairie. 2004. Bacterial metabolism and growth efficiency in lakes: the importance of phosphorus availability. Limnology and Oceanography 49:137-147.

Spencer, R. G. M., G. R. Aiken, K. P. Wickland, R. G. Striegl, AND P. J. HeRnEs. 2008. Seasonal and spatial variability in dissolved organic matter quantity and composition from the Yukon River basin, Alaska. Global Biogeochemical Cycles 22. doi:10.1029/2008GB003231.

Stedmon, C. A., AND R. BRO. 2008. Characterizing dissolved organic matter fluorescence with parallel factor analysis: a tutorial. Limnology and Oceanography: Methods 6: 572-579.

Stedmon, C. A., And S. Markager. 2005. Resolving the variability in dissolved organic matter fluorescence in a temperate estuary and its catchment using PARAFAC analysis. Limnology and Oceanography 50:686-697.

Strauss, E. A., and G. A. Lamberti. 2002. Effect of dissolved organic carbon quality on microbial decomposition and nitrification rates in stream sediments. Freshwater Biology 47:65-74.

Thackway, R., AND I. D. CResswell. 1995. An interim biogeographic regionalisation for Australia: a framework for setting priorities in the National Reserves System Cooperative Program. Reserve System Unit, Australian Nature Conservation Agency, Canberra, Australia. (Available from: http://www.environment.gov.au/parks/nrs/ science/bioregion-framework/ibra/).

Walsh, C. J., A. H. Roy, J. W. Feminella, P. D. Cottingham, P. M. Groffman, And R. P. Morgan. 2005. The urban stream syndrome: current knowledge and the search for a cure. Lournal of the North American Benthological Society 24: 706-723.

Weishatr, J. L., G. R. Aiken, B. A. Bergamaschi, M. S. Fram, R. FUJII, AND K. MOPPER. 2003. Evaluation of specific ultraviolet absorbance as an indicator of the chemical composition and reactivity of dissolved organic carbon. Environmental Science and Technology 37:4702-4708.

Wells, P., AND J. Hickey. 1999. Wet sclerophyll, mixed and swamp forest. Pages 224-243 in J. B. Reid, R. S. Hill, M. J. Brown, and M. J. Hovenden (editors). Vegetation of Tasmania. Monotone Art Printers, Hobart, Australia.

Wetzel, R. G. 1992. Gradient-dominated ecosystems: sources and regulatory functions of dissolved organic 
matter in freshwater ecosystems. Hydrobiologia 229: 181-198.

White, P. A., J. KalfF, J. B. Rasmussen, and J. M. Gasol. 1991. The effect of temperature and algal biomass on bacterial production and specific growth rate in freshwater and marine habitats. Microbial Ecology 21:99-118.

Wickland, K. P., J. C. NefF, And G. R. Aiken. 2007. Dissolved organic carbon in Alaskan boreal forest: sources, chemical characteristics, and biodegradability. Ecosvstems 10:1323-1340.

Williams, C. J., Y. Yamashita, H. F. Wilson, R. Jaffé, and M. A. Xenopoulos. 2010. Unraveling the role of land use and microbial activity in shaping dissolved organic matter characteristics in stream ecosystems. Limnology and Oceanography 55:1159-1171.

Wipfli, M. S., J. S. RichardSON, AND R. J. NAimAn. 2007. Ecological linkages between headwaters and down- stream ecosystems: transport of organic matter, invertebrates, and wood down headwater channels. Iournal of the American Water Resources Association 43: $72-85$.

Yamashita, Y., B. D. Kloeppel, J. Knoepr, G. L. Zausen, and R. JAFFÉ. 2011. Effects of watershed history on dissolved organic matter characteristics in headwater streams. Ecosvstems 14:1110-1122.

Yamashita, Y., L. J. Scinto, N. Maie, And R. Jaffé. 2010. Dissolved organic matter characteristics across a subtropical wetland's landscape: application of optical properties in the assessment of environmental dynamics. Ecosvstems 13:1006-1019.

Received: 30 October 2012 Accepted: 3 May 2013 